\title{
Population screening for TAVI procedure
}

\author{
A Redzek $^{1 *}$, L Velicki $^{1}$, M Petrovic ${ }^{2}$, B Mihajlovic $^{1}$, M Fabri ${ }^{1}$, S Nicin ${ }^{1}$ \\ From 23rd World Congress of the World Society of Cardio-Thoracic Surgeons \\ Split, Croatia. 12-15 September 2013
}

\section{Background}

Transcatheter aortic valve implantation (TAVI) is an alternative that offers hope to patients who are older, or have contraindication to conventional surgical aortic valve replacement due to considerable comorbidities. In our country there is about 500 to 1000 patients, older than 80 years needing this, less invasive procedure. The aim of this study was to asses the number of high-risk patients with severe aortic stenosis, hospitalized at our institute, which are candidates for percutaneous aortic valve implantation.

\section{Methods}

We have prospectively analyzed all patients who were hospitalized at our institute, between April 2011 and November 2012, due to severe aortic stenosis. Each of these patients was discussed in relation to inclusive criteria for TAVI.

\section{Results}

In the period of 20 months, there were 374 patients hospitalized due to severe aortic stenosis at our institute. In the group of patients older than 80 years (13.6\%; 51/374), low ejection fraction, pulmonary hypertension, significant carotid stenosis, atrial fibrillation and significant mitral regurgitation were registered in 5.9\%, 29.4\%, 13.7\% , 21.6\% and $25.5 \%$ respectively. On the other hand, percentage of surgicaly treated patients with severe aortic stenosis decreases in older gruops of patients, especially in the age over 80 years $(90.2 \%)$. Most of patients from this subgroup were treated conservatively due to high operative risk for conventional surgerical procedure.

\section{Conclusion}

The data obtained in this study indicate a high percentage of conservatively treated patients with severe aortic

\footnotetext{
* Correspondence: sci@ikvbv.ns.ac.rs

${ }^{1}$ Cardiovascular Surgery, Institute of Cardiovascular Diseases Vojvodina, Serbia
} Full list of author information is available at the end of the article stenosis and high operative risk in patients over 80 years. This data confirm needs for implementation of TAVI in our population.

\section{Authors' details \\ ${ }^{1}$ Cardiovascular Surgery, Institute of Cardiovascular Diseases Vojvodina, Serbia. ${ }^{2}$ Cardiology, Institute of Cardiovascular Diseases Vojvodina, Serbia.}

Published: 11 September 2013

doi:10.1186/1749-8090-8-S1-O46

Cite this article as: Redzek et al:: Population screening for TAVI

procedure. Journal of Cardiothoracic Surgery 2013 8(Suppl 1):○46.

\section{Submit your next manuscript to BioMed Central and take full advantage of: \\ - Convenient online submission \\ - Thorough peer review \\ - No space constraints or color figure charges \\ - Immediate publication on acceptance \\ - Inclusion in PubMed, CAS, Scopus and Google Scholar \\ - Research which is freely available for redistribution \\ Submit your manuscript at www.biomedcentral.com/submit}

